\title{
Implementasi Metode Fuzzy Sugeno Untuk Prediksi Penentuan Porsi Dana Pembangunan Perumahan
}

\author{
${ }^{1}$ Budy Satria, ${ }^{2}$ Teuku Radillah, ${ }^{3}$ Leonard Tambunan, ${ }^{4}$ Muhammad Iqbal \\ 1,2,3,4 AMIK Mitra Gama, Indonesia \\ budysatriadeveloper@gmail.com , t.radillah@gmail.com, tambunan.leonard81@gmail.com, iqbal.kun@gmail.com
}

\begin{tabular}{l}
\hline Article Info \\
\hline Article history: \\
Received, 11-01-2021 \\
Revised, 15-01-2021 \\
Accepted, 29-01-2021 \\
\hline
\end{tabular}

\section{Kata Kunci:}

fuzzy

prediksi

perumahan

inferensi

variabel

\begin{tabular}{l}
\hline \hline \\
Keywords: \\
fuzzy \\
prediction \\
housing \\
inference \\
variable
\end{tabular}

\begin{abstract}
ABSTRAK
CV. Fujiyama Abadi Takengon adalah sebuah perusahaan yang bergerak dalam bidang perumahan. Selama ini, untuk melakukan proses perhitungan porsi dana pembangunan perumahan masih menggunakan sistem secara manual. Hal ini dapat memungkinkan adanya terjadi kesalahan dalam proses pendataan porsi dana pembangunan 3 tipe perumahan yaitu 21, 36 dan 45 yang akan diberikan kepada calon pembeli. Tujuan dari penelitian ini adalah untuk membuat suatu sistem perhitungan porsi dana perumahan yang terkomputerisasi sehingga seluruh data dana pembangunan perumahan diolah melalui sistem komputer. Sehingga data dana pebangunan perumahan dapat diolah dengan cepat dan tepat. Metode yang digunakan dalam penelitian ini adalah menggunakan fuzzy sugeno, metode ini diimplementasikan untuk menentukan tingkat keakuratan perhitungan berdasarkan jumlah dan luas bangunan. Hasil dari penelitian ini adalah bahwa metode fuzzy sugeno mampu melakukan prediksi perhitungan jika lantai rumah seharga Rp4.000.000, Bahan seharga Rp.27.000.000 dan Rangka seharga Rp6.500.000 maka perkiraan dana pembangunan yang dibutuhkan yaitu sekitar Rp. 79.835.000 setelah dilakukan proses inferensi dan defuzifikasi.
\end{abstract}

\section{ABSTRACT}

CV. Fujiyama Abadi Takengon is a company engaged in the housing sector. So far, the process of calculating the portion of housing development funds is still using the system manually. This could allow errors to occur in the data collection process for the portion of funds for the construction of 3 types of housing, namely 21,36 and 45 which will be given to prospective buyers. The purpose of this research is to create a computerized system for calculating the portion of housing funds so that all data on housing development funds are processed through a computer system. So that housing development fund data can be processed quickly and accurately. The method used in this research is to use Sugeno fuzzy, this method is implemented to determine the level of accuracy of calculations based on the number and area of buildings. The result of this research is that Sugeno fuzzy method is able to predict calculations if the house floor costs Rp. 4,000,000, material costs Rp. 27,000,000 and the frame is Rp. 79,835,000 after the inference and defuzification process was carried out

\section{Penulis Korespondensi:}

Budy Satria,

Program Studi Teknik Komputer,

AMIK Mitra Gama,

Email: budysatriadeveloper@gmail.com

\section{PENDAHULUAN}

CV. Fujiyama Abadi Takengon merupakan salah satu perusahaan yang bergerak dalam bidang perumahan. Dalam hal penghitungan porsi dana pembangunan perumahan masih menggunakan sistem secara manual. Dalam hal tersebut, perlu untuk membuat suatu sistem komputer di mana data dana pembangunan perumahan 
diolah melalui sistem komputer. Sehingga data dana pebangunan perumahan dapat diolah dengan cepat dan tepat. Maka dari itu untuk menentukan porsi dana pembangunan perumahan berdasarkan jumlah dan luas bangunan dibutuhkan sebuah sistem untuk penentuan porsi dana pembangunan, untuk itu diperlukan sebuah metode yang mendukung keputusan tersebut yang sesuai dengan permasalahan yang akan dipecahkan [1]. Untuk mendapatkan perkiraan porsi dana yang tepat, dalam penelitian ini menggunakan variabel-variabel perhitungan fuzzy sebagai berikut yaitu Luas Bangunan, Kualitas Bahan dan Besarnya Dana Pembangunan Rumah itu sendiri, berdasarkan data dari CV. Fujiyama Abadi. Metode yang dipakai dalam menentukan porsi dana pembangunan perumahan ini adalah Logika Fuzzy dengan Metode Fuzzy Sugeno yang di dalam teori ini keanggotaan suatu elemen di dalam himpunan dinyatakan dengan derajat keanggotaan (membership values) dan himpunan fuzzy. Dalam penelitian ini dibutuhkan beberapa teori yang berhubungan dengan permasalahan yang ada, diantaranya fuzzy sugeno dan prediksi. Logika fuzzy adalah konsep matematika yang digunakan untuk mewakili atau memanipulasi ketidakjelasan dari informasi yang kurang tepat [2] sedangkan Prediksi merupakan suatu kegiatan yang memperkirakan apa yang terjadi pada masa akan datang [3]. Pada penelitian sebelumnya, metode fuzzy sugeno dilakukan untuk menentukan harga jual sepeda motor bekas [4]. Penerapan Metode Fuzzy Sugeno untuk Menentukan Harga Jual Sepeda Motor Bekas dengan variabel- variabel input, yaitu : tahun motor, kondisi fisik motor, plat nomor, dan harga beli motor. Metode fuzzy sugeno juga pernah diterapkan pada embedded system untuk mendeteksi kondisi kebakaran dalam ruangan [5]. Proses fuzzyfikasi menggunakan 3 variabel yaitu variabel asap, suhu, dan api. Dalam penelitian lain, penerapan metode fuzzy sugeno juga dilakukan untuk pengukuran keakuratan jarak pada pintu otomatis di CV Bejo Perkasa. Hasil dari penelitian ini adalah sistem pengukuran keakuratan jarak menggunakan sensor ultrasonic dengan pendekatan metode fuzzy sugeno sangat akurat di perhitunganya [6].

Tidak hanya pada prediksi, metode fuzzy sugeno juga diterapkan pada sistem pendukung keputusan. Sistem Pendukung Keputusan menentukan Tenaga Medis Berprestasi Menggunakan Metode Fuzzy [7]. Selain itu, metode fuzzy sugeno juga diterapkan untuk menentukan jumlah produksi roti minimum (Studi kasus :PT. Jordan Bakery Pekanbaru) [8]. Sistem pendukung keputusan adalah bagian dari sistem informasi berbasis komputer termasuk sistem berbasis pengetahuan atau manajemen pengetahuan yang dipakai untuk mendukung pengambilan keputusan dalam suatu organisasi atau perusahaan [9]. Sistem pendukung keputusan hanya menyediakan keputusan alternatif, sedangkan keputusan akhir masih ditentukan oleh pengambil keputusan [10]. Penerapan fuzzy sugeno pada sistem pendukung keputusan untuk menentukan status gizi balita [11]. Berdasarkan hasil pengujian terhadap sistem pendukung keputusan (SPK) status gizi yang telah dibangun dengan menggunakan metode fuzzy sugeno dan pengujian menggunakan standar baku antropometri memiliki hasil $84 \%$ dari 25 data yang diujikan terdapat 4 yang tidak sesuai, sehingga dapat disimpulkan bahwa unjuk kerja sistem berhasil.

Penelitian sebelumnya, metode fuzzy sugeno juga diterapkan pada Analisis Perkiraan Jumlah Produksi Tahu Menggunakan Metode Fuzzy Sugeno [12]. Dalam metode ini menggunakan tiga variabel yaitu, variabel permintaan, variabel persediaan dan variabel produksi. Masing-masing variabel memiliki tiga himpunan Fuzzy, variabel permintaan terdiri dari turun, sedang dan naik. Variabel persediaan terdiri dari sedikit, sedang dan banyak. Dan variabel produksi terdiri dari berkurang, lumayan dan bertambah. Dari hasil data uji yang dilakukan dengan Metode Sugeno terdapat selisih error sebesar 2,148\% artinya tinggat kebenaran sebesar 97,852\%. Sehingga metode ini dapat diterapkan pada industri tahu XYZ dalam perkiraan jumlah produksi tahu untuk periode berikutnya. Metode fuzzy sugeno juga dilakukan untuk akurasi penentuan suhu kandang ayam pedaging. Hasil dari pengujian terhadap metode ini adalah suhu ideal yang sesuai berdasarkan inputan umur dan suhu kandang ayam pedaging. Dari uji coba yang telah dilakukan dapat disimpulkan Metode Fuzzy Sugeno yang di implementasikan dengan mikrokontroler Arduino Mega 2560 dapat meninggkat akurasi suhu ideal pada kandang ayam pedaging [13]. Dari uraian penelitian terdahulu, maka penelitian ini menggunakan metode fuzzy sugeno untuk prediksi penentuan porsi dana pembangunan dengan 3 tipe perumahan, yaitu 21, 36 dan 45 .

\section{METODE PENELITIAN}

Penalaran dengan metode fuzzy sugeno hampir sama dengan penalaran Mamdani, hanya saja output (konsekuen) sistem tidak berupa himpunan fuzzy, melainkan berupa konstanta atau persamaan linear. Metode ini diperkenalkan oleh Takagi-Sugeno Kang pada tahun 1985 [14]. Pada penelitian ini dapat dijelaskan prosedur penelitian menggunakan metode algoritma fuzzy sugeno yaitu :

1. Menentukan data awal

2. Menentukan variable dan domain dari tiap-tiap atribut kriteria.

3. Melakukan proses fuzzyfikasi. 
JSAI : Journal Scientific and Applied Informatics

Vol. 4, No. 01, Januari 2021, hal. 75 84

E-ISSN: 2614-3054; P-ISSN: 2614-3062, accredited by Kemenristekdikti, Sinta 5

DOI: 10.36085

Fuzzyfikasi merupakan proses mentransformasikan data pengamatan ke dalam bentuk himpunan Fuzzy.

Secara umum, Terdapat 2 bentuk dari model fuzzy sugeno, yaitu Orde-Nol dan Orde-Satu [15]. Untuk bentuk Orde-Nol sebagai berikut :

IF $\left(X_{1}\right.$ is $\left.A_{l}\right) \bullet\left(X_{1}\right.$ is $\left.A_{l}\right) \bullet\left(X_{3}\right.$ is $\left.A_{3}\right) \cdot \ldots . . .\left(X_{n}\right.$ is $\left.A_{n}\right)$ THEN $Z=K$

Dengan $A i$ adalah himpunan Fuzzy ke-i sebagai anteseden, dan k adalah suatu konstanta (tegas) sebagai konsekuen.

Untuk bentuk Orde-Satu sebagai berikut :

IF $\left(X_{I}\right.$ is $\left.A_{l}\right) \cdot \ldots \ldots \cdot\left(X_{n}\right.$ is $\left.A_{n}\right)$ THEN $Z=P_{l} * X_{l}+\ldots . .+P_{n} * X_{n}+q$

1. Melakukan proses inferensi.

2. Melakukan proses defuzzifikasi.

Defuzzyfikasi menggunakan persamaan berikut ini :

$\frac{\sum a-\text { pred } *(\text { konsekuen })}{\left.\sum \text { (konsekuen }\right)}$

Metode penelitian menggunakan fuzzy sugeno digambarkan melalui flowchart seperti terlihat pada Gambar 1 di bawah ini.

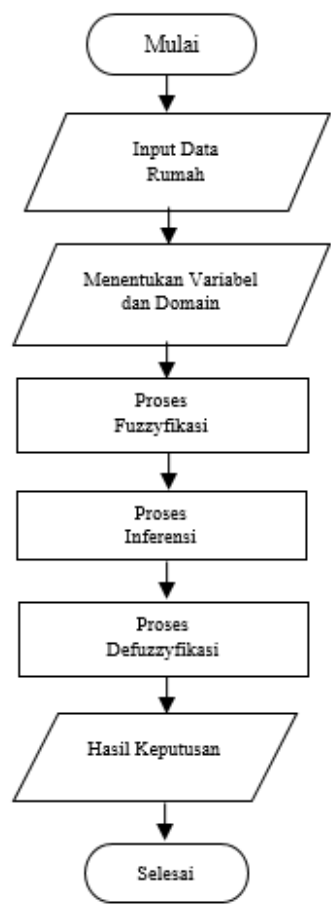

Gambar 1. Flowchart Penelitian

Dari Gambar 1 diatas, dapat diketahui proses yang akan dilakukan pada penelitian ini yaitu diawalai dengan kondisi mulai, memasukkan data rumah yang telah tersedia. Dari data rumah yang ada diubah menjadi bentuk variabel dan domain. Proses fuzzyfikasi yaitu proses di mana data inputan nilai yang bersifat pasti (crips input) ke dalam bentuk fuzzy input. langkah selanjutnya adalah melakukan proses inferensi, yaitu proses yang dilakukan dengan menggunakan teori himpunan fuzzy yang berbentuk IF-THEN dan penalaran fuzzy. Selanjtnya proses defuzzyfikasi dan terakhir hasil keputusan. 
JSAI : Journal Scientific and Applied Informatics

Vol. 4, No. 01, Januari 2021, hal. 75 84

E-ISSN: 2614-3054; P-ISSN: 2614-3062, accredited by Kemenristekdikti, Sinta 5

DOI: 10.36085

\section{HASIL DAN ANALISIS}

\subsection{Menentukan data awal seperti Tabel 1 di bawah ini.}

Tabel 1. Data Variabel dan Domain

\begin{tabular}{cccccc}
\hline No & Tipe & Lantai & Bahan & Rangka & Dana Pembangunan \\
\hline 1 & 36 A & Murah & Sedang & Murah & 53.560 .000 \\
\hline 2 & 36 B & Sedang & Sedang & Murah & 56.720 .000 \\
\hline 3 & 21 A & Murah & Murah & Sedang & 42.250 .000 \\
\hline 4 & 45 & Mahal & Mahal & Sedang & 74.670 .000 \\
\hline 5 & 21 B & Murah & Murah & Murah & 40.135 .000 \\
\hline 6 & 45 B & Mahal & Mahal & Mahal & 85.000 .000 \\
\hline 7 & 36 C & Sedang & Sedang & Murah & 60.000 .000 \\
\hline 8 & 21 C & Murah & Murah & Murah & 43.100 .000 \\
\hline
\end{tabular}

Dalam penelitian ini akan dicari berapa perkiraan Dana Pembangunan yang dibutuhkan jika rumah yang akan dibangun dengan Lantai Keramik seharga [Rp 4.000.000], Bahan berkualitas sedang seharga [Rp.27.000.000] dan Rangka Baja seharga [Rp 6.500.000]. Dari Data Pembangunan Rumah di atas dapat kita tentukan 3 Variabel yaitu Lantai, Bahan dan Rangka.

Domain Lantai : murah [Rp. 2.000.000], sedang [Rp 3.500.000], mahal [Rp. 5.500.000];

Domain Bahan : murah [15.000.000], sedang [25.000.000], mahal [45.000.000];

Domain Rangka : murah [2.500.000], sedang [5.000.000], mahal [7.500.000].

\subsection{Fuzzifikasi}

Dalam penelitian ini digunakan beberapa variabel seperti variabel lantai, bahan dan rangka serta input tertentu. Berikut proses fuzzyfikasi yang dilakukan.

\subsubsection{Variabel Lantai}

Kurva untuk fungsi keanggotaan $(\mu)$ pada variabel lantai dengan nilai murah, sedang, mahal dapat dilihat pada Gambar di bawah ini.

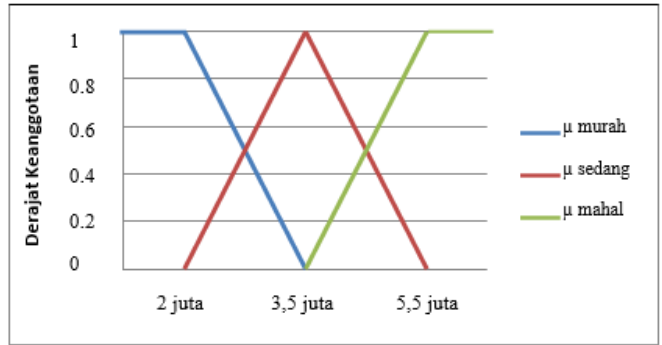

Gambar 2. Kurva Lantai

Sedangkan untuk fungsi keanggotaan untuk variabel lantai dapat dilihat pada Tabel 3 di bawah ini.

Tabel 3 Fungsi Keanggotaan Variabel Lantai.

\begin{tabular}{c|c|c}
\hline Himpunan Fuzzy & Batasan & Derajat Keanggotaan $(\mu)$ \\
\hline \multirow{4}{*}{$\begin{array}{c}\mu \text { Murah } \\
(\mathrm{x})\end{array}$} & $\mathrm{x} \leq 2$ & $\frac{3,5-x}{3,5-2}$ \\
\cline { 2 - 3 } & $2 \leq \mathrm{x} \leq 3,5$ & 0 \\
\cline { 2 - 3 } & $\mathrm{x} \geq 3,5$ & $\frac{x-2}{3,5-2}$ \\
\cline { 2 - 3 } & $\mathrm{x} \leq 2$ & $\frac{5,5-x}{5,5-3,5}$ \\
\hline \multirow{4}{*}{$\begin{array}{c}\mu \text { Sedang } \\
\text { (x) }\end{array}$} & $3,5 \leq \mathrm{x} \leq 5,5$ & 0 \\
\cline { 2 - 3 } & $\mathrm{x} \geq 5,5$ & \multicolumn{2}{c}{} \\
\cline { 2 - 3 } & &
\end{tabular}


JSAI : Journal Scientific and Applied Informatics

Vol. 4, No. 01, Januari 2021, hal. 75 84

E-ISSN: 2614-3054; P-ISSN: 2614-3062, accredited by Kemenristekdikti, Sinta 5

DOI: 10.36085

\begin{tabular}{c|c|c}
\hline \multirow{4}{*}{$\begin{array}{c}\mu \text { Mahal } \\
(\mathrm{x})\end{array}$} & $\mathrm{x} \leq 3,5$ & 0 \\
\cline { 2 - 3 } & $3,5 \leq \mathrm{x} \leq 5,5$ & $\frac{x-3,5}{5,5-3,5}$ \\
\cline { 2 - 3 } & $\mathrm{x} \geq 5,5$ & 1 \\
\hline
\end{tabular}

Kemudian mencari nilai keanggotaan untuk variable Lantai [Rp 4.000.000] di bawah ini: $\mu \operatorname{Murah}[4]=0$

$\mu$ Sedang $[4]=\frac{5,5-x}{5,5-3,5}=\frac{5,5-4}{5,5-3,5}=0,75$

$\mu$ Mahal [4] $=\frac{x-3,5}{5,5-3,5}=\frac{4-3,5}{5,5-3,5}=0,25$

\subsubsection{Variabel Bahan}

Kurva untuk fungsi keanggotaan $(\mu)$ pada variabel lantai dengan nilai murah, sedang, mahal dapat dilihat pada Gambar 2 di bawah ini.

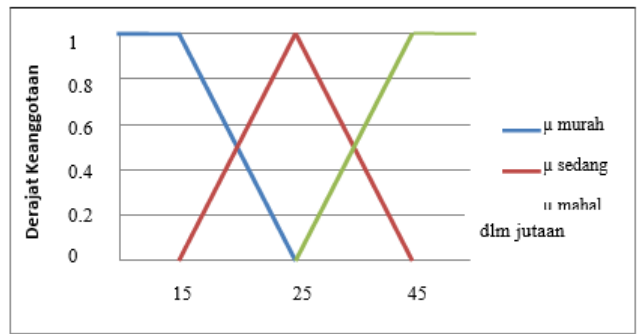

Gambar 3. Kurva Bahan

Sedangkan fungsi keanggotaan untuk variabel Bahan dilihat pada Tabel di bawah ini.

Tabel 4 Fungsi Keanggotaan Variabel Bahan

\begin{tabular}{|c|c|c|}
\hline Himpunan Fuzzy & Batasan & Derajat Keanggotaan $(\mu)$ \\
\hline \multirow{3}{*}{$\begin{array}{c}\mu \text { Murah } \\
(\mathrm{x})\end{array}$} & $x \leq 15$ & 1 \\
\hline & $15 \leq x \leq 25$ & $\frac{25-x}{25-15}$ \\
\hline & $x \geq 25$ & 0 \\
\hline \multirow{4}{*}{$\begin{array}{c}\mu \text { Sedang } \\
(\mathrm{x})\end{array}$} & $x \leq 15$ & 0 \\
\hline & $15 \leq x \leq 25$ & $\frac{x-15}{25-15}$ \\
\hline & $25 \leq x \leq 45$ & $\frac{45-x}{45-25}$ \\
\hline & $x \geq 45$ & 0 \\
\hline \multirow{3}{*}{$\begin{array}{c}\mu \text { Mahal } \\
(\mathrm{x})\end{array}$} & $x \leq 25$ & 0 \\
\hline & $25 \leq x \leq 45$ & $\frac{x-25}{45-25}$ \\
\hline & $x \geq 45$ & 1 \\
\hline
\end{tabular}

Kemudian mencari nilai keanggotaan untuk variable Bahan [Rp.27.000.000] di bawah ini: $\mu$ Murah [27] $=0$

$\mu$ Sedang[27] $=\frac{45-x}{45-25}=\frac{45-27}{45-25}=0,9$

$\mu$ Mahal [27] $=\frac{x-25}{45-25}=\frac{27-25}{45-25}=0,1$

\subsubsection{Variabel Rangka}

Kurva untuk fungsi keanggotaan $(\mu)$ pada variabel lantai dengan nilai murah, sedang, mahal dapat dilihat pada Gambar 3 di bawah ini. 


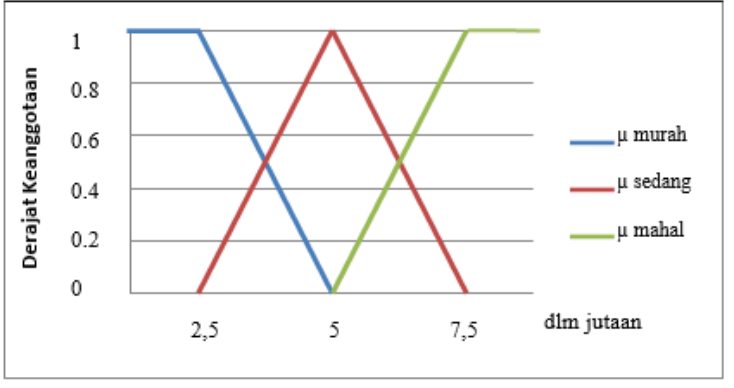

Gambar 4. Kurva Rangka

Sedangkan fungsi keanggotaan untuk variabel Rangka dilihat pada Tabel 5 di bawah ini.

Tabel 5 Fungsi Keanggotaan Variabel Rangka

\begin{tabular}{|c|c|c|}
\hline Himpunan Fuzzy & Batasan & Derajat Keanggotaan $(\mu)$ \\
\hline \multirow{3}{*}{$\begin{array}{l}\mu \text { Murah } \\
(\mathrm{x})\end{array}$} & $x \leq 2$ & 1 \\
\hline & $2 \leq x \leq 3,5$ & $\frac{5-x}{5-2.5}$ \\
\hline & $x \geq 3,5$ & 0 \\
\hline \multirow{4}{*}{$\begin{array}{c}\mu \text { Sedang } \\
\text { (x) }\end{array}$} & $x \leq 2$ & 0 \\
\hline & $2 \leq x \leq 3,5$ & $\frac{x-2,5}{5-25}$ \\
\hline & $3,5 \leq x \leq 5,5$ & $\frac{7,5-x}{7,5-5}$ \\
\hline & $x \geq 5,5$ & \\
\hline \multirow{3}{*}{$\begin{array}{l}\mu \text { Mahal } \\
(\mathrm{x})\end{array}$} & $x \leq 3,5$ & 0 \\
\hline & $3,5 \leq x \leq 5,5$ & $\frac{x-5}{7.5-5}$ \\
\hline & $x \geq 5,5$ & 1 \\
\hline
\end{tabular}

Kemudian mencari nilai keanggotaan untuk variable Rangka [Rp 6.500.000] di bawah ini : $\mu$ Murah $[6,5]=0$

$\mu$ Sedang $[6,5]=\frac{7,5-x}{7,5-5}=\frac{7,5-6,5}{7,5-5}=0,4$

$\mu$ Mahal $[6,5]=\frac{x-5}{7,5-5}=\frac{6,5-5}{7,5-5}=0,6$

\subsubsection{Inferensi}

Berikut ini adalah proses inferensi menggunakan penalaran fuzzy:

[R1] If (Lantai is Murah) and (Bahan is Sedang) and (Rangka is Murah) Then Dana Pembangunan = 53.560.000

$\alpha$-pred $1=\min (0 ; 0,9 ; 0)=0$

$\mathrm{Z} 1=53.560 .000$

[R2] If (Lantai is Sedang) and (Bahan is Sedang) and (Rangka is Murah) Then Dana Pembangunan = 56.720.000

$\alpha$-pred $2=\min (0,75 ; 0,9 ; 0)=0$

$\mathrm{Z} 2=56.720 .000$

[R3] If (Lantai is Murah) and (Bahan is Murah) and (Rangka is Sedang) Then Dana Pembangunan = 42.250.000

$\alpha$-pred $3=\min (0 ; 0 ; 0,4)=0$

$\mathrm{Z} 3=42.250 .000$

[R4] If (Lantai is Mahal) and (Bahan is Mahal) and (Rangka is Sedang) Then Dana Pembangunan = 74.670.000

$\alpha$-pred $4=\min (0,25 ; 0,1 ; 0,4)=0,1$

$\mathrm{Z} 4=74.670 .000$ 
JSAI : Journal Scientific and Applied Informatics

Vol. 4, No. 01, Januari 2021, hal. 75 84

E-ISSN: 2614-3054; P-ISSN: 2614-3062, accredited by Kemenristekdikti, Sinta 5

DOI: 10.36085

[R5] If (Lantai is Murah) and (Bahan is Murah) and (Rangka is Murah) Then Dana Pembangunan = 40.135.000

$\alpha$-pred $5=\min (0 ; 0 ; 0)=0$

$\mathrm{Z} 5=40.135 .000$

[R6] If (Lantai is Mahal) and (Bahan is Mahal) and (Rangka is Mahal) Then Dana Pembangunan = 85.000.000

$\alpha$-pred $6=\min (0.25 ; 0.1 ; 0.6)=0.1$

$\mathrm{Z} 6=85.000 .000$

[R7] If (Lantai is Sedang) and (Bahan is Sedang) and (Rangka is Murah) Then Dana Pembangunan = 60.000.000

$\alpha$-pred $7=\min (0.75 ; 0.9 ; 0)=0$

$\mathrm{Z7}=60.000 .000$

[R8] If (Lantai is Murah) and (Bahan is Murah) and (Rangka is Murah) Then Dana Pembangunan = 43.100.000

$\alpha$-pred $8=\min (0 ; 0 ; 0)=0$

$\mathrm{Z} 8=43.100 .000$

\subsubsection{Proses Defuzifikasi}

Setelah dilakukan langkah If - Then, maka langkah terakhir yaitu proses defuzzyfikasi. Dengan menggunakan persamaan di bawah ini :

Nilai Crips $=\frac{\sum \alpha-\text { pred } *(\text { Konsekuen })}{\sum(\text { Konsekuen })}$

$$
\begin{aligned}
& =\frac{\left(\alpha 1 * Z_{1}\right)+\left(\alpha 2 * Z_{2}\right)+\left(\alpha 3 * Z_{3}\right)+\left(\alpha 4 * Z_{4}\right)+\left(\alpha 5 * Z_{5}\right)+\left(\alpha 6 * Z_{6}\right)+\left(\alpha 7 * Z_{7}\right)+\left(\alpha 8 * Z_{8}\right)}{(\alpha-1)+(\alpha-2)+(\alpha-3)+(\alpha-4)+(\alpha-5)+(\alpha-6)+(\alpha-7)+(\alpha-8)} \\
& =\frac{(0 * 1 * 74.670 .000)+(0 * 43.560 .000)+(0 * 135.000)+(0.1 * 720.000)+(0 * 42.250 .000)+}{(0)+(0)+(0)+(0,1)+(0)+(0,1)+(0)+(0)} \\
& =\frac{0+0+0+7.467 .000+0+000.500 .000}{0,2} \\
& =\text { Rp. 79.835.000 }
\end{aligned}
$$

Hasil perhitungan dari metode Fuzzy Sugeno perkiraan dana pembangunan yang dibutuhkan yaitu sekitar Rp. 79.835.000. Hasil perhitungan ini dapat dijadikan acuan pengambil keputusan dalam menentukan Porsi Dana Pembangunan Rumah.

\subsubsection{Implementasi Dalam Aplikasi}

A. Form login

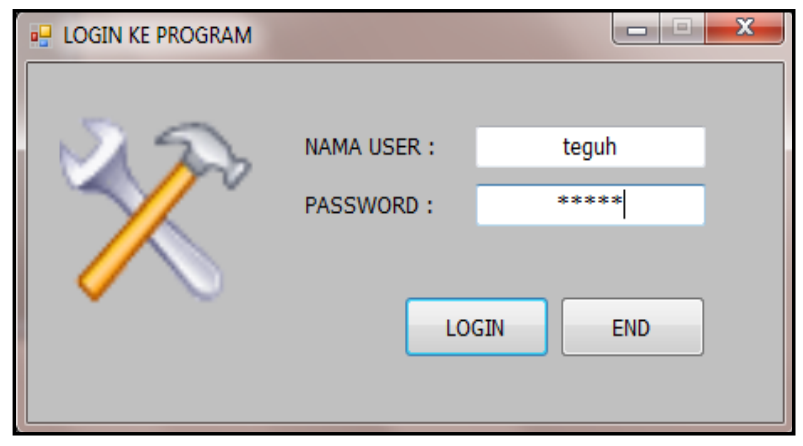

Gambar 5. Tampilan Form Login 
JSAI : Journal Scientific and Applied Informatics

Vol. 4, No. 01, Januari 2021, hal. 75 84

E-ISSN: 2614-3054; P-ISSN: 2614-3062, accredited by Kemenristekdikti, Sinta 5

DOI: 10.36085

\section{B. Menu Utama}

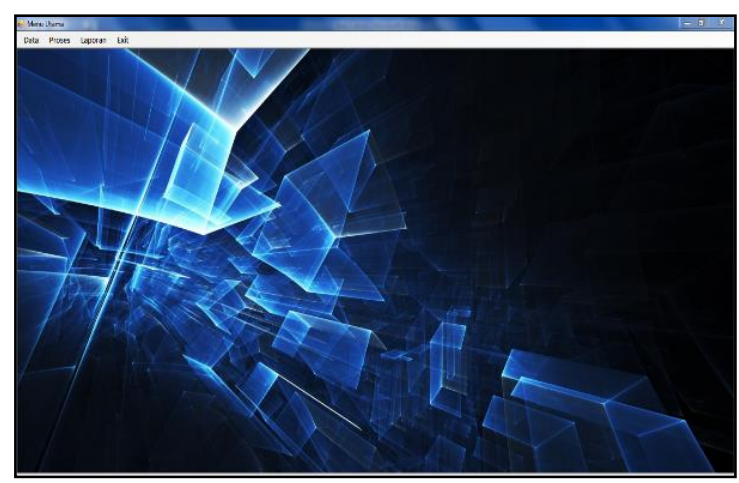

Gambar 6. Tampilan Menu Utama

Pada tampilan menu utama terdapat 3 menu yaitu Menu Data, Menu Proses, Menu Laporan dan Exit (Keluar) aplikasi.

\section{Form Input Data Rumah}

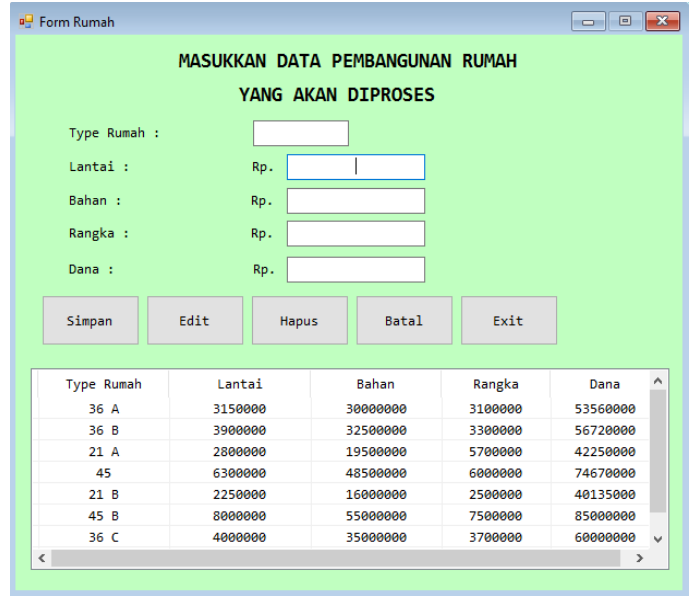

Gambar 7. Tampilan Input Data Rumah

\section{Form Fuzzifikasi}

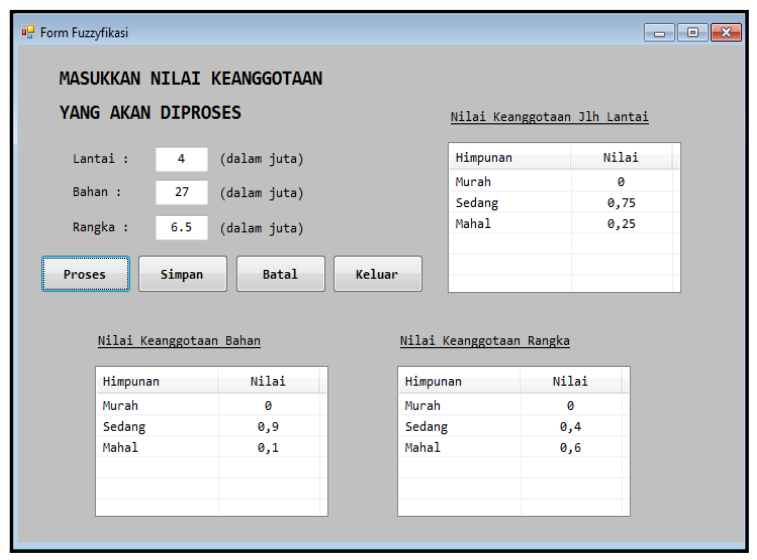

Gambar 8. Tampilan Form Fuzzifikasi 


\section{E. Proses Inferensi dan Defuzzifikasi}

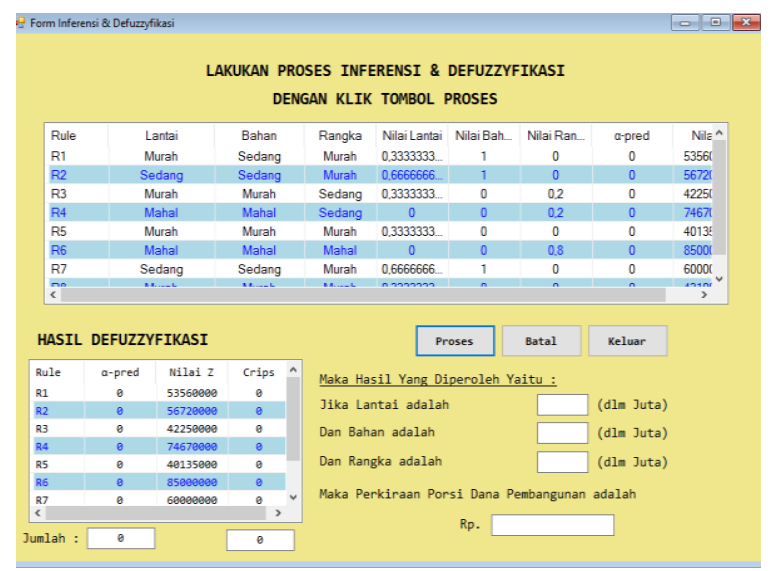

Gambar 9. Tampilan Form Inferensi dan Defuzzifikasi

\section{KESIMPULAN}

A. Implementasi Metode Fuzzy Sugeno Untuk Prediksi Penentuan Porsi Dana Pembangunan Perumahan dengan 3 tipe perumahan, yaitu 21, 36 dan 45, maka diperoleh prediksi hasil perhitungan perkiraan dana pembangunan yang dibutuhkan yaitu sekitar Rp. 79.835 .000 berdasarkan variabel lantai, variabel bahan dan variabel rangka.

B. Hasil penelitian ini diimplementasikan ke dalam aplikasi yang berisi input data pembangunan rumah, nilai keanggotaan, proses inferensi, proses defuzzifikasi dan hasil dari defuzifikasi yang bisa digunakan oleh CV. Fujiyama Abadi Takengon dalam prediksi penentuan porsi dana pembangunan perumahan.

\section{UCAPAN TERIMA KASIH}

Terima kasih banyak kami ucapkan kepada Direktur AMIK Mitra Gama yang telah memberikan kesempatan kepada peneliti untuk melaksanakan penelitian. Terima kasih juga Kepada Ketua Program Studi Teknik Komputer dan Ketua LPPM AMIK Mitra Gama yang selalu memberikan dukungan kepada kami para peneliti. Serta kepada pengelola jurnal JSAI (Journal Scientific and Applied Informatics) yang bersedia menerima dan mempublikasikan artikel penelitian ini dengan penuh kerja sama yang baik.

\section{REFERENSI}

[1] D. Guswandi, "Sistem Pendukung Keputusan Bantuan Bedah Rumah Menggunakan Metode Simple Additive Weighting Pada Badan Amil Zakat," Maj. Ilm. UPI YPTK Padang, vol. 24, no. 1, pp. 221234, 2017.

[2] S. Sakinah, Y. Widiastiwi, and A. Zaidiah, "Implementasi Metode Fuzzy Sugeno Pada Proses Penyiangan Koleksi Buku di Perpustakaan Universitas Indonesia," Semin. Nas. Mhs. Ilmu Komput. dan Apl., pp. 622-636, 2020.

[3] B. Satria, "Prediksi Volume Penggunaan Air PDAM Menggunakan Metode Jaringan Syaraf Tiruan Backpropagation," J. RESTI (Rekayasa Sist. dan Teknol. Informasi), vol. 2, no. 3, pp. 674-684, 2018.

[4] A. H. Agustin, G. K. Gandhiadi, and T. B. Oka, "Penerapan Metode Fuzzy Sugeno Untuk Menentukan Harga Jual Sepeda Motor Bekas,” E-Jurnal Mat., vol. 5, no. 4, pp. 176-182, 2016.

[5] R. A. Purnomo, D. Syauqy, and M. H. Hanafi, "Implementasi Metode Fuzzy Sugeno Pada Embedded System Untuk Mendeteksi Kondisi Kebakaran Dalam Ruangan," J. Pengemb. Teknol. Inf. dan Ilmu Komput., vol. 2, no. 4, pp. 1428-1435, 2018.

[6] R. Rizky, T. Hidayat, A. Hardianto, and Z. Hakim, "Penerapa Metode Fuzzy Sugeno Untuk pengukuran Keakuratan Jarak Pada Pintu Otomatis di CV Bejo Perkasa," J. Tek. Inform. Unika St. Thomas, vol. 05, no. 01, pp. 33-42, 2020. 
[7] S. N. Rizki, "Sistem Pendukung Keputusan Menentukan Tenaga Medis Berprestasi Menggunakan Metode Fuzzy," J. Edik Inform. (Peneliitian Bid. Komput. Sains dan Pendidik. Inform., vol. 4, no. 2, pp. 72-83, 2018.

[8] S. Basriati, E. Safitri, Rahmawati, and W. Wulandari, "Penerapan Metode Fuzzy Sugeno untuk Menentukan Jumlah Produksi Roti Optimum," Semin. Nas. Teknol. Informasi, Komun. dan Ind. 11 Fak. Sains dan Teknol. UIN Sultan Syarif Kasim Riau Pekanbaru, no. November, pp. 471-477, 2019.

[9] B. Satria, "Implementation Of Additive Ratio Assessment (ARAS) Method On Decision Support System For Recipient Of Inhabitable House," JITK (Jurnal Ilmu Pengetah. Dan Teknol. Komputer), vol. 6, no. 1, pp. 121-128, 2020.

[10] I. Nur Okta and B. Satria, "Sistem Pendukung Keputusan Dalam Menentukan Perbaikan Jalan Rusak Dengan Menggunakan Metode Simple Additive Weighting (SAW) (Studi Kasus : Kabupaten Kuantan Singingi)," Jar. Sist. Inf. Robot., vol. 3, no. 1, pp. 194-202, 2019.

[11] A. Romadhon and A. S. Purnomo, "Sistem Pendukung Keputusan Untuk Menentukan Status Gizi Balita Menggunakan Metode Fuzzy Inferensi Sugeno (Berdasarkan Metode Antropometri)," Informatics J., vol. 1, no. 3, pp. 78-87, 2016.

[12] S. Nurdini, G. W. Nurcahyo, and J. Santony, "Analisis Perkiraan Jumlah Produksi Tahu Menggunakan Metode Fuzzy Sugeno,” J. Sistim Inf. dan Teknol., vol. 1, no. 3, pp. 18-23, 2019.

[13] D. Y. Darmawi, G. W. Nurcahyo, and Sumijan, "Fuzzy Sistem Fuzzy Menggunakan Metode Sugeno Dalam Akurasi Penentuan Suhu Kandang Ayam Pedaging," J. Inf. dan Teknol., vol. 3, no. 2, pp. 72 77, 2020.

[14] D. Mulyadi, "Komparasi Metode Logika Fuzzy Mamdani dan Metode Logika Fuzzy Sugeno Sebagai Pendukung Keputusan Seleksi Bertahap," J. Ilm. Teknol. dan Inf., vol. 6, no. 1, pp. 1-16, 2016.

[15] S. Batubara, "Analisis Perbandingan Metode Fuzzy Mamdani Dan Fuzzy Sugeno Untuk Penentuan Kualitas Cor Beton Instan," It J. Res. Dev., vol. 2, no. 1, pp. 1-11, 2017. 